DOI:

\title{
Rancang Bangun Sistem Informasi Akuntansi HPP Berdasarkan Pesanan Pada Usaha Industri Rumahan Manufaktur
}

\author{
Widy Firdha Lestari, Apriani Puti Purfini \\ Universitas Komputer Indonesia \\ Email: widyfirdhakurniawan@gmail.com, apriani.puti.purfini@email.unikom.ac.id
}

\section{Keywords: \\ HPP; industry at home; information system.}

\begin{abstract}
The purpose of this research to engineering information system accounting HPP on order for cottage industries and the organizational structure. This study using method of development information system the iteration with structured. The results of research in the form of application cost of good sold in accordance with standard and the proposed organizational structure.
\end{abstract}

\begin{abstract}
Abstrak
Tujuan penelitian ini melakukan rancang bangun sistem informasi akuntansi hpp berdasarkan pesanan pada usaha industri rumahan dan mengusulkan struktur organisasi. Penelitian ini menggunakan metode pengembangan sistem informasi iterasi dengan pendekatan terstruktur. Hasil dari penelitian berupa aplikasi harga pokok produksi yang sesuai dengan standar akuntansi dan usulan struktur organisasi.
\end{abstract}

\section{PENDAHULUAN}

Penentuan harga pokok produksi (HPP) pada industri rumahan manufaktur yang tepat sangatlah penting. "Penentuan harga pokok produksi merupakan hal yang sangat penting mengingat manfaat informasi harga pokok produksi adalah menentukan harga jual produk serta penentuan harga pokok persediaan produk jadi dan produk dalam proses yang akan disajikan dalam neraca"'[1] . Sukirno "menyatakan bahwa semakin rendah harga suatu barang maka semakin banyak permintaan terhadap barang tersebut, sebaliknya makin tinggi harga suatu barang makin sedikit permintaan terhadap barang tersebut"'[8].

Penelitian sebelumnya Stanly Dodi Setiawan"membuat sebuah perangkat lunak perhitungan harga pokok standar dan harga pokok produksi aktual berdasarkan pesanan,yang menyajikan informasi harga pokok standar, harga pokok produksi aktual serta perbandingan antara harga pokok standar dan harga pokok produksi aktual"[6]. Humisar Hasugian"membuat sebuah perangkat lunak penentuan hpp, yang menyajikan informasi estimasi hpp, nilai aktual hpp, serta proses kegiatan administrasi produksi, selain itu juga menyajikan informasi pelaporan penjualan, produksi, laba kotor setiap pesanan"[3].

Unit analisis pada penelitian merupakan perusahaan industri rumahan manufaktur yang memproduksi pakaian/fashion terutama pakaian muslim wanita. Penulis melakukan penelitian pada bagian produksi untuk mengetahui gambaran secara langsung tentang hpp pada perusahaan tersebut. Pembuatan laporan hpp masih belum terkomputerisasi dan belum adanya pencatatan jurnal umum, buku besar, serta laporan keuangan yang memenuhi standar akuntansi keuangan, berdasarkan hasil survei ke tempat penelitian menyatakan bahwa hal tersebut menimbulkan pembuatan laporan keuangan kurang akurat dan membutuhkan waktu yang lama dalam 
Nama penulis : Widy Firdha Lestari, Apriani Puti Purfini

Judu : Rancangan Bangun Sistem Informasi

Akuntansi HPP Berdasarkan Pesanan

Pada Usaha Industri Rumahan

Manufaktur
@ is The Best

Vol. 03 No. 02. Desember 2018: Hal 322-327

P-ISSN : 2252-9853

pembuatannya. Belum terdapat format dokumen yang baku dari mulai proses pemesanan barang ,proses produksi sampai dengan distribusi barang. Industri rumahan kesulitan dalam menentukan harga penjualan dikarenakan belum menerapkan standar perhitungan hpp.Tujuan penelitian untuk mengetahui prosedur Hpp berdasarkan pesanan pada usaha industri rumahan, untuk mengusulkan struktur organisasi pada industri rumahan dan untuk rancang bangun sistem informasi akuntansi hpp berdasarkan pesanan pada industri rumahan. Penelitian ini membuat perangkat lunak hpp berdasarkan pesanan, yang menyajikan informasi pesanan konsumen,supplier,order produksi, daftar bahan baku,pengadaan bahan baku,pemakaian bahan baku,biaya tenaga kerja,biaya overhead pabrik, jurnal umum, buku besar, neraca saldo dan laporan hpp.

\section{METODE}

\section{Metode Penelitian}

Metode penelitian adalah cara mendapatkan informasi dan data untuk penelitian. Definisi Metode penelitian adalah "metode penelitian pada dasarnya merupakan cara ilmiah untuk mendapatkan data dengan tujuan dan kegunaan tertentu"[7]. Metode penelitian yang peneliti gunakan adalah metode survei.

\section{Metodologi Pengembangan Sistem}

Metodologi pengembangan sistem adalah prosedur atau konsep untuk menyempurnakan suatu sistem informasi. Definisi metodologi pengembangan sistem menurut Jogyanto "metodologi pengembangan sistem berarti adalah metode-metode, prosedur-prosedur, konsep-konsep pekerjaan, aturan-aturan dan postulat-postulat yang akan digunakan untuk mengembangkan suatu sistem informasi"[4]. Penelitian menggunakan metodologi pengembangan sistem terstruktur.

\section{Model Pengembangan Sistem}

Definisi dari model pengembangan sistem adalah "Pengembangan sistem adalah menyusun suatu sistem yang baru untuk menggantikan sistem yang lama secara keseluruhan atau memperbaiki sistem yang telah ada" [4].

Model pengembangan sistem yang digunakan oleh peneliti adalah iterasi seperti terlihat pada gambar 1, definisi iterasi adalah "model pengembangan sistem adalah tahapan-tahapan tersebut dilaksanakan dengan pemakai iterasi atau dimana suatu proses dilaksanakan secara berulang-ulang sampai didapatkan hasil yang diinginkan" [9].

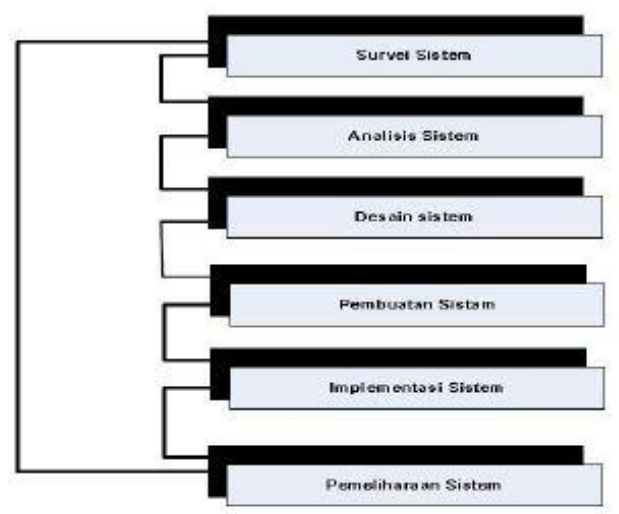

Gambar 1 Model Pengembangan Iterasi (Sutarbi 2012)

\section{4. $\quad$ Metode Pencatatan Akuntansi}

Pencatatan akuntansi terdiri dari dua pencatatan yaitu metode Cash basic dan accrual basic.Menurut Halim "cash basic accounting atau akuntansi berbasis kas, yaitu menetapkan bahwa pencatatan transaksi ekonomi hanya dilakukan apabila transaksi tersebut merencanakan perubahan pada kas[2]. Accrual basic accounting (akuntansi akrual), yaitu dasar akuntansi yang mengakhiri 
Nama penulis : Widy Firdha Lestari, Apriani Puti Purfini

Judu : Rancangan Bangun Sistem Informasi

Akuntansi HPP Berdasarkan Pesanan

Pada Usaha Industri Rumahan

Manufaktur
@ is The Best

Vol. 03 No. 02. Desember 2018: Hal 322-327

akuntansi dan dasar peristiwa tersebut terjadi dan bukan hanya pada saat kas atau setara kas di terima atau dibayar".Penelitian ini menggunakan metode pencatatan akuntansi Acrual Basic.

\section{Metode HPP}

Penelitian ini menggunakan metode hpp berdasarkan pesanan, karena produksi dilakukan berdasarkan pesanan dari konsumen.Menurut Usry "hpp berdasarkan pesanan adalah biaya produksi diakumulasikan untuk setiap pesanan yang terpisah, suatu pesanan adalah output yang diidentifikasikan untuk memenuhi pesanan pelanggan tertentu atau mengisi kembali suatu item dari persediaan"'[10].

Menurut Mulyadi "Adapun jenis biaya terbagi menjadi tiga yaitu Bahan baku merupakan bahan yang membentuk bagian menyeluruh produk jadi ,tenaga kerja merupakan usaha fisik atau mental yang dikeluarkan karyawan untuk mengolah produk biaya tenaga kerja adalah harga yang dibebankan untuk penggunaan tenaga manusia tersebut, biaya overhead pabrik adalah biaya produksi selain biaya bahan baku dan biaya tenaga kerja langsung" [5].

\section{HASIL DAN PEMBAHASAN}

\section{Usulan Struktur Organisasi}

Struktur organisasi sangat penting dalam sebuah perusahaan.Dengan adanya struktur organisasi akan jelas mengenai pembagian tugas ,tanggungjawab dan wewenang setiap bagian, oleh karena itu berdasarkan hasil analisis terhadap sistem yang berjalan penelitian ini memberikan usulan berupa struktur organisasiyang berkaitan dengan sistem informasi akuntansi hpp terlihat pada gambar 2. Peneliti tidak mena mbah orang hanya terdapat penambahan admin dan bagian gudang. Bagian gudang dan admin dibawah tanggung jawab owner secara langsung, yang berfungsi untuk dirangkap oleh owner, dilakukan owner secara langsung tapi tidak tergambarkan pada struktur organisasi yang berjalan, oleh sebab itu peniliti mengusulkan struktur organisasi dengan menambahkan admin dan gudang agar lebih terstruktur dan sesuai dengan job Description.

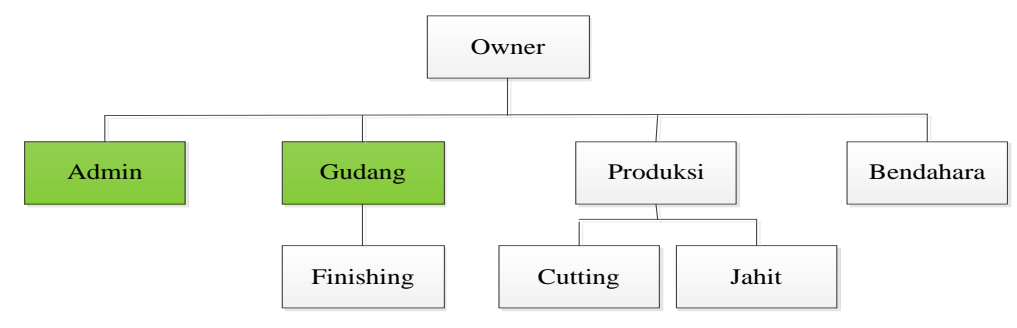

Bagian yang penulis usulkan

\section{Gambar 2 Usulan Struktur Organisasi}

\section{Kode Akun dan Nama Akun}

Komponen penting pada sistem informasi akuntansi yaitu kode akun . Dikarenakan belum diterapkannya standar akuntansi di perusahaan maka penelitian ini mengusulkan kode akun terlihat pada tabel 1 ,kode akun yang diusulkan merupakan kode akun yang digunakan pada sistem informasi akuntansi hpp,

Tabel 1 Kode Akun dan Nama Akun 
Nama penulis : Widy Firdha Lestari, Apriani Puti Purfini Judu

: Rancangan Bangun Sistem Informasi Akuntansi HPP Berdasarkan Pesanan Pada Usaha Industri Rumahan Manufaktur
@ is The Best Vol. 03 No. 02. Desember 2018: Hal 322-327 P-ISSN : 2252-9853

\begin{tabular}{|l|c|}
\hline \multicolumn{1}{|c|}{ Nama Akun } & Kode Akun \\
\hline Kas & 111 \\
\hline Persediaan Bahan Baku & 112 \\
\hline Persediaan Bahan Penolong & 113 \\
\hline Biaya Tenaga Kerja Tidak Langsung & 503 \\
\hline BOP Sesungguhnya & 517 \\
\hline Upah & 513 \\
\hline Barang dalam Proses-BBB & 611 \\
\hline Barang DalamProses-BTKL & 612 \\
\hline Barang DalamProses-BOP & 613 \\
\hline
\end{tabular}

\section{ERD (Entity Relationship Diagram)}

Entity Relationship Diagram yang diusulkan pada sistem informasi akuntansi hpp berdasarkan pesanan terlihat pada gambar 3

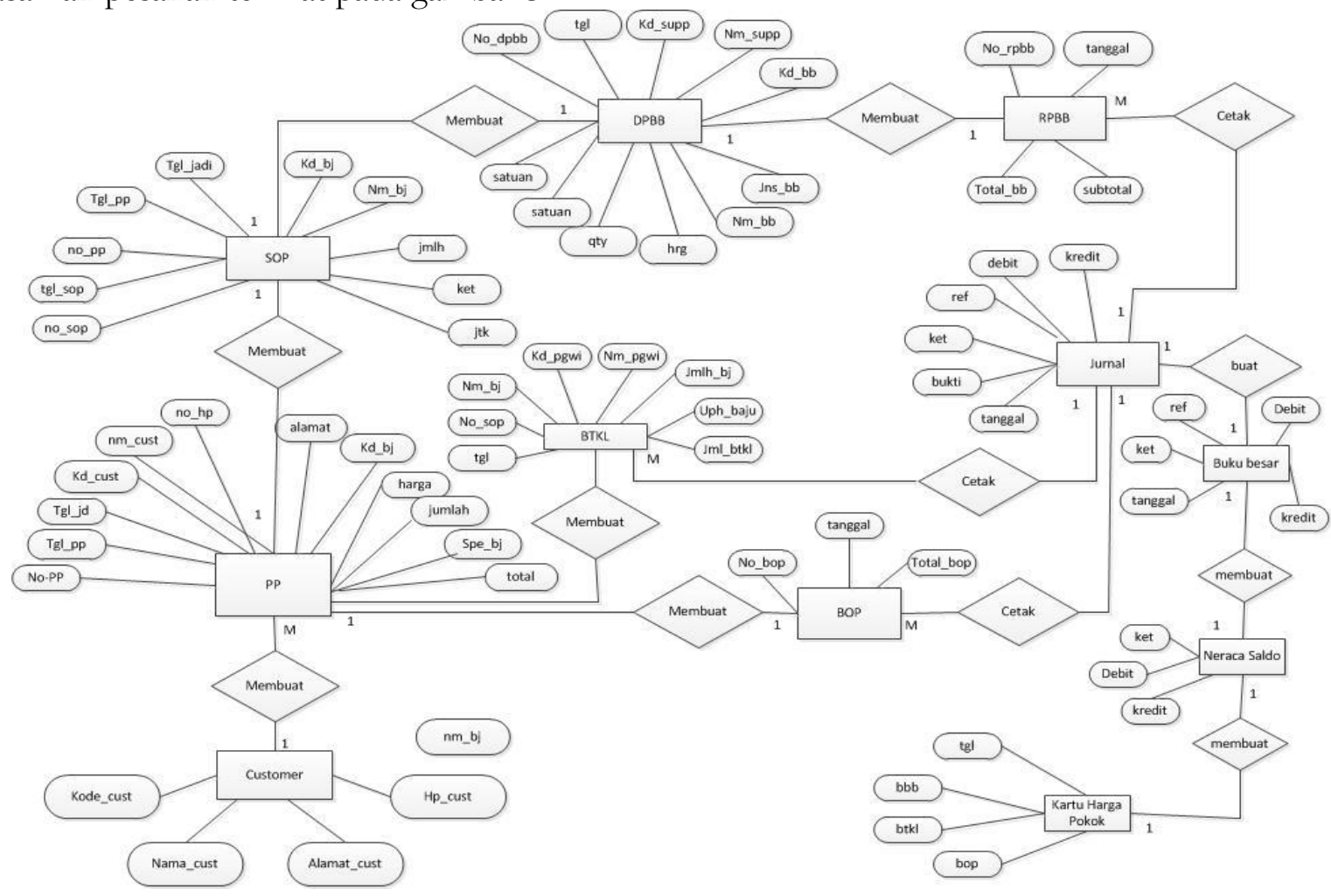

Gambar 3 ERD yang Diusulkan

\section{Perancangan Struktur Menu}

Struktur menu pada sistem informasi akuntansi hpp berdasarkan pesanan terlihat pada gambar 4 melibatkan 4 pengguna dan terdapat menu pesanan konsumen,supplier,order produksi, daftar bahan baku,pengadaan bahan baku,pemakaian bahan baku,biaya tenaga kerja,biaya overhead pabrik, jurnal umum, buku besar, neraca saldo dan laporan hpp. 
Nama penulis : Widy Firdha Lestari, Apriani Puti Purfini Judu

: Rancangan Bangun Sistem Informasi

Akuntansi HPP Berdasarkan Pesanan

Pada Usaha Industri Rumahan

Manufaktur

Vol. 03 No. 02. Desember 2018: Hal 322-327

P-ISSN : 2252-9853

\section{Tampilan Pengguna}

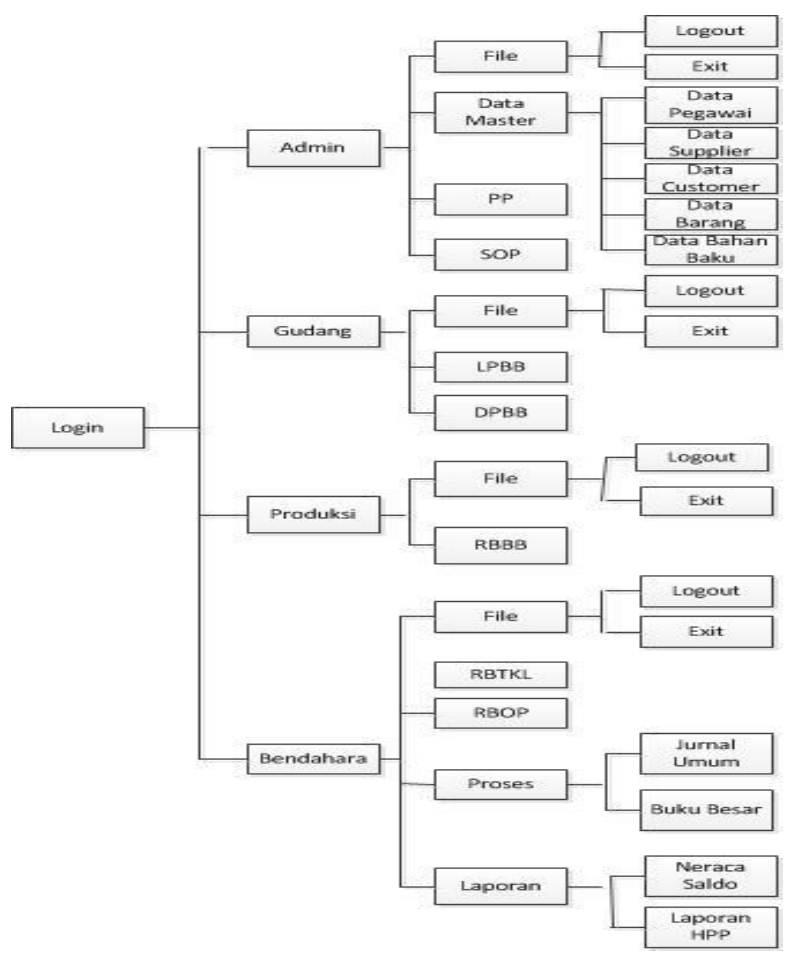

Gambar 4 Struktur Menu

Hasil dari penelitian ini yaitu berupa perangkat lunak hpp berdasarkan pesanan. Gambar 5,6,7 dan 8 merupakan sebagian tampilan yang terdapat pada perangkat lunak tersebut.

\begin{tabular}{|c|c|c|c|c|}
\hline \multicolumn{5}{|c|}{$\begin{array}{l}\text { INDY COLLECTION } \\
\text { JURNAL UMUM }\end{array}$} \\
\hline \multicolumn{5}{|c|}{ Periode Agustus 2016} \\
\hline tanggal & keterangan & ref & debit & kredit \\
\hline $26 / 08 / 2016$ & Persediaan Bahan Baku & 1.1 .2 & $1.200 .000,00$ & 0,00 \\
\hline 26/08/2016 & Kas & 1.1 .1 & 0,00 & 1.200.000,00 \\
\hline $26 / 08 / 2016$ & Barang dalam Proses-BBB & 6.1 .1 & 1.200.000,00 & 0,00 \\
\hline 26/08/2016 & Persediaan Bahan Baku & 1.1 .2 & 0,00 & $1.200 .000,00$ \\
\hline $26 / 08 / 2016$ & Barang dalam Proses-BTKL & 6.1 .2 & $320.000,00$ & 0,00 \\
\hline $26 / 08 / 2016$ & Upah & 5.1.1 & 0,00 & $320.000,00$ \\
\hline $26 / 08 / 2016$ & Barang dalam Proses-BOP & 6.1 .3 & $480.000,00$ & 0,00 \\
\hline $26 / 08 / 2016$ & BOP yang dibebankan & 5.1 .2 & 0,00 & $480.000,00$ \\
\hline
\end{tabular}

Gambar 5 Tampilan Halaman Jurnal Umum

27/08/2016
\begin{tabular}{|l|l|c|r|r|r|r|} 
BUKU BESAR UMUM \\
Periode Agustus 2016
\end{tabular}
\begin{tabular}{|l|l|r|r|r|r|r|} 
Nama Akun : BTKL \\
\hline tanggal & keterangan & ref & debit & kredit & d_k & saldo \\
\hline $19 / 08 / 2016$ & Upah & 5.1 .1 & $320.000,00$ & 0,00 & D & $320.000,00$ \\
\hline $26 / 08 / 2016$ & Upah & 5.1 .1 & $320.000,00$ & 0,00 & D & $640.000,00$ \\
\hline $26 / 08 / 2016$ & Upah & 5.1 .1 & $320.000,00$ & 0,00 & D & $960.000,00$ \\
\hline
\end{tabular}

Gambar 6 Tampilan Halaman Buku Besar BTKL NERACA SALDO

Periode Agustus 2016

\begin{tabular}{|c|l|c|c|}
\hline \multicolumn{1}{|c|}{ Periode Agustus 2016 } \\
\hline ref & \multicolumn{1}{|c|}{ keterangan } & debit & kredit \\
\hline 1.1 .1 & kas & 0,00 & $1.200 .000,00$ \\
\hline 1.1 .2 & persediaan bahan baku & 0,00 & 0,00 \\
\hline 5.1 .2 & BOP yang dibebankan & 0,00 & $480.000,00$ \\
\hline 5.1 .3 & Upah & 0,00 & $320.000,00$ \\
\hline 6.1 .1 & Barang dalam Proses-BBB & $1.200 .000,00$ & 0,00 \\
\hline 6.1 .2 & Barang dalam Proses-BTKL & $320.000,00$ & 0,00 \\
\hline 6.1 .3 & Barang dalam Proses-BOP & $480.000,00$ & 0,00 \\
\hline \multicolumn{2}{|c|}{ Total } & $\mathbf{2 . 0 0 0 . 0 0 0 , 0 0}$ & $\mathbf{2 . 0 0 0 . 0 0 0 , 0 0}$ \\
\hline
\end{tabular}

Gambar 7 Tampilan Neraca Saldo 
Nama penulis : Widy Firdha Lestari, Apriani Puti Purfini Judu : Rancangan Bangun Sistem Informasi Akuntansi HPP Berdasarkan Pesanan Pada Usaha Industri Rumahan Manufaktur
@ is The Best

Vol. 03 No. 02. Desember 2018: Hal 322-327

P-ISSN : 2252-9853

Laporan Harga Pokok Produksi

Periode Agustus 2016

$27 / 08 / 2016$

\begin{tabular}{|lr|}
\hline Bahan Langsung: & \\
\hline Persediaan Awal Periode & 0 \\
\hline Pembelian bahan Baku & $1.200 .000,00$ \\
\hline Total Bahan yang Tersedia & $1.200 .000,00$ \\
\hline Dikurangi Persediaan bahan akhir periode & $1.200 .000,00$ \\
\hline Bahan Baku Langsung yang digunakan & 0 \\
\hline Tenaga Kerja Langsung & $320.000,00$ \\
\hline Bahan Baku Penolong yang digunakan & 0 \\
\hline Biaya Overhead Pabrik yang dibebankan & $2.000 .0000,00$ \\
\hline Total Biaya Produksi yang dikeluarkan & 0 \\
\hline Di tambah persediaan produk dalam proses akhir periode & $2.000 .000,00$ \\
\hline Total Biaya Produksi yang dibebankan & 0 \\
\hline Di kurangi persediaan produk dalam proses akhir periode & $2.000 .000,00$ \\
\hline Harga Pokok Produksi & \\
\hline
\end{tabular}

Gambar 8 Tampilan Laporan Hpp

\section{PENUTUP}

Perhitungan hpp yang sesuai dengan standar akuntansi yang berlaku sangat diperlukan bagi industri rumahan. Penelitian ini membuat rancang bangun sistem informasi akuntansi hpp berdasarkan pesanan pada industri rumahan yang menyajikan informasi pesanan konsumen,supplier,order produksi, daftar bahan baku,pengadaan bahan baku,pemakaian bahan baku,biaya tenaga kerja,biaya overhead pabrik, jurnal umum, buku besar, neraca saldo dan laporan hpp.Dengan adanya penelitian ini diharapkan akan membantu meningkatkan produktivitas dan daya saing industri rumahan.

\section{DAFTAR PUSTAKA}

[1] Batubara, Helmina. 2013. "Penentuan Harga Pokok Produksi Berdasarkan Metode Full Costing Pada pembuatan Etalase Kaca dan Aluminium Di UD Istana Aluminium Manado." Jurnal EMBA 217-224.

[2] Halim, Abdul. 2007. Akuntansi Sektor Publik Kuntansi Keuangan Daerah. Jakarta: Salemba Empat.

[3] Humisar Hasugian, Fajri Sidik. 2014. "rancang bangun sistem informasi penentuan harga pokok produksi studi kasus : PT.fajar Metalindo Abadi." Seminar Nasional Sistem Informasi Indonesia. Surabaya: ITS. 197-202.

[4] Jogyanto. 2010. Analisis dan Desain Sistem Informasi. Yogyakarta: Andi Offset.

[5] Mulyadi. 2015. Akuntansi Biaya Edisi ke-5. Yogyakarta: UPP-STIM YKPN.

[6] Stanly Dodi Setiawan, Arifin Puji Widodo ,Anjik Sukmaaji. 2012. "Rancang Bangun Sistem Informasi Penentuan Harga Pokok Produksi dan Harga Standar Pada CV.Anugrah Mulya Rejeki." Jurnal JSIKA 40-47.

[7] Sugiyono. 2011. Metode Penelitian Kuantitatif,Kualitatif,dan R\&D. Bandung: Alfabeta.

[8] Sukirno, Sadono. 2005. Mikro Ekonomi Teori Pengantar. Jakarta: PT Raja Grafindo Persada.

[9] Sutarbi, Tata. 2012. Analisis Sistem Informasi. Yogyakarta: Andi Offset.

[10] Usry, Carter And Milton F. 2006. Cost Accounting 13th Edition, Penerjemah Krista. Jakarta: Salemba Empat. 